\title{
Kangaroo Mother Care and Neonatal Outcomes in the Pediatric Department of CHU Gabriel Toure
}

\author{
Fousseyni Traorée1,2*, Hawa G. Diall'1, Karamoko Sacko1,2, Belco Maiga ${ }^{1,2}$, Oumar Coulibaly ${ }^{1}$, \\ Isabelle Traore ${ }^{1}$, Leyla Maiga', Lala N. Sidibe',2, Pierre Togo', Abdoul Karim Doumbia1, \\ Djeneba Konaté1,2, Fatoumata Leonie Diakité1,2, Ibrahima Ahamadou1, Adama Dembélé1, \\ Abdoul Aziz Diakité1,2, Fatoumata Dicko Traoré1,2, Mariam Sylla ${ }^{1,2}$, Boubacar Togo ${ }^{1,2}$ \\ ${ }^{1}$ Department of Pediatrics, CHU Gabriel Toure, Bamako, Mali \\ ${ }^{2}$ Faculty of Medicine and Odontostomatology, Bamako, Mali \\ Email: ${ }^{\star d r f o u s s e y n i t r a o r e @ g m a i l . c o m ~}$
}

How to cite this paper: Traoré, F., Diall, H.G., Sacko, K., Maiga, B., Coulibaly, O., Traore, I., Maiga, L., Sidibe, L.N., Togo, P., Doumbia, A.K., Konaté, D., Diakité, F.L., Ahamadou, I., Dembélé, A., Diakité, A.A., Traoré, F.D., Sylla, M. and Togo, B. (2022) Kangaroo Mother Care and Neonatal Outcomes in the Pediatric Department of CHU Gabriel Toure. Open Journal of Pediatrics, 12, 179-187.

https://doi.org/10.4236/ojped.2022.121019

Received: January 20, 2022

Accepted: March 5, 2022

Published: March 8, 2022

Copyright $\odot 2022$ by author(s) and Scientific Research Publishing Inc. This work is licensed under the Creative Commons Attribution International License (CC BY 4.0).

http://creativecommons.org/licenses/by/4.0/

\begin{abstract}
Introduction: In Mali, prematurity is currently the leading cause of neonatal morbidity and mortality at the Gabriel Toure Hospital. Kangaroo Mother" care is an efficient and effective alternative care strategy for preterm and low birth weight babies. This study aimed to evaluate the epidemio-clinical and therapeutic profile of premature/hypotrophic newborns admitted to the "Kangaroo-mother" care unit. Material and method: It was a retrospective study from 01/01/2010 to 31/12/2012. Were included all stable preterm with gestational age between 28 - 37 weeks and hypotrophic newborns with a birth weight $<10^{\text {th }}$ percentile for gestational age. Results: One thousand and eighty-four patients $(\mathrm{n}=1084)$ were included. The sex ratio was $1.2(\mathrm{~F}=592 ; \mathrm{M}=492)$. The mean birth weight was $1300 \mathrm{~g}$ (600 $\mathrm{g}$ $2000 \mathrm{~g})$. The mean gestational age was $32.69(28-37)$. The mean age of the mothers was 24 years (13 - 45 years). Single pregnancies accounted for $85.1 \%$. Discontinuation of care was $56 \%$. Follow-up to 24 months was effective in $14 \%$ of patients. Sixteen percent of the patients died $(n=176)$. The mothers' lack of schooling $(\mathrm{p}=0.03)$ and birth weight $<1000 \mathrm{~g}(\mathrm{p}=0.003)$ were the major factors in the patients' mortality. Conclusion: The kangaroo-mother care is an alternative means to improve the survival of preterm and low birth weight babies in Mali.
\end{abstract}

\section{Keywords}

Newborns, Kangaroo-Mother Care, Mali 


\section{Introduction}

Neonatal mortality in Mali is among the highest in the world, with one death for every twenty-eight live births. Prematurity is a major factor, with a rate of 11.6 per 100,000 births [1]. It is essential that preterm and low birth weight infants receive appropriate care and feeding during their first 28 days of life. Adequate care for these newborns is a huge problem in many developing countries. The "kangaroo-mother" program began in 1978 in Colombia [2]. Initially experimental, the method involved mothers holding their premature babies skin-to-skin permanently. Recent research has shown that this technique compares favorably with the use of incubators to maintain the normal temperature of preterm infants in the absence of incubators. The kangaroo method is mainly used for newborns with a birth weight of less than 2000 grams and for premature babies. It helps the premature child to integrate more quickly into his family, with social, psycho-emotional and economic benefits. In Mali, the care of premature babies is a huge issue, due to limited resources.

\section{Objectives}

The objective of this study was to evaluate the épidémio-clinical and outcome of premature/hypotrophic newborns admitted to the "Kangaroo-mother" care unit of the paediatric department of the Gabriel Toure university Hospital.

\section{Patients and Methods}

It was a retrospective study which from $01 / 01 / 2010$ to $31 / 12 / 2012$. Were included all stable preterm with gestational age between 28 - 37 weeks and hypotrophic newborns with a birth weight $<10^{\text {th }}$ percentile for gestational age.

\subsection{The "Kangaroo-Mother" Procedure}

The newborn was placed almost naked (except for a cap, nappy and socks) between the mother's breasts (for as long as possible, 24 hours a day), in a strictly vertical position, with his belly in direct contact with his mother's skin, his head turned to the side, his arms and legs spread out. This position is similar to "frog position". The sling holds the baby who can be fed in this position. Mother should sleep in a reclining/half sitting position. The kangaroo position is maintained until the baby can no longer tolerate it and feels the need to come out. Feeding is usually started with a feeding tube and then, depending on the level of neurological maturation, given by syringe, spoon and finally by suckling or bottle feeding. Breast milk is preferred. Baby's formula (premature milk) can be used too. A weight gain per day should be around $10-20 \mathrm{~g} / \mathrm{kg} / \mathrm{day}$. If the mother is deemed capable of continuing home care, further follow-up of the baby continues until 24 months (corrected age for premature infants) of life.

\subsection{Data Collection and Analysis}

The data were collected from the medical records of newborns in the kanga- 
roo-mother care unit. The variables studied were: Socio-demographic and obstetrical parameters of the mothers; Anthropometric and clinical parameters of the newborns. The data were entered and analysed on SPSS version 20. Discontinuation of follow-up refers to cases of interruption of care for a precise reason and in agreement with the unit's personnel. A patient was considered lost to follow-up if he was no longer seen at follow-up appointments and did not report back. The care abandonment was defined as a cessation of follow-up without the agreement of the team staff for any reason.

\subsection{Ethical Aspects}

The consent was obtained from the parents before inclusion in the study and the confidentiality of data was respected.

\section{Results}

During the study period, 4471 neonates with a birth weight $\leq 2000$ g were admitted to the neonatal unit; of these, 1084 were admitted to the kangaroo unit (24\%).

\subsection{Characteristics of Newborns}

There were 150 pairs of twins, 8 triplets and 3 quadruplets. The majority of the newborns (87\%) were delivered by vaginal way. The sex ratio was $1.2(\mathrm{~F}=592$; $\mathrm{M}=492)$. The mean birth weight was $1300 \mathrm{~g}(600 \mathrm{~g}-2000 \mathrm{~g})$. The mean gestational age was 32.69 (28 - 37).

Discontinuation of care was $56 \%$, the majority of which occurred before 40 weeks' gestation (40\%). Follow-up up to 24 months was effective in $14 \%$ of patients. Sixteen percent of the patients died $(n=176)$, and the lethality rate was $6.4 \%$. The mothers' lack of schooling $(\mathrm{p}=0.03)$ and birth weight $<1000 \mathrm{~g}(\mathrm{p}=$ 0.003 ) were the major factors in the patients' mortality.

\subsection{Socio-Demographic Characteristics of Mothers}

The average age of the mothers was 24 years (13 - 45 years). Thirty-seven percent of the mothers were primiparous. Eighty-six percent of the mothers were living with a partner. The average number of prenatal visits was 2.8 . Ten per cent of the mothers had not attended any antenatal care. Malaria accounted for $17.5 \%$ of the conditions during pregnancy $(n=172)$, followed by anaemia $(n=147 ; 15 \%)$.

\subsection{Obstetrical Characteristics of Mothers}

Single pregnancies accounted for $85.1 \%$. Delivery took place in second-level health facilities in $48 \%$ of cases. Delivery was carried out by a health professional in $98 \%$ of cases. The average number of pregnancies per woman was 3 (1 - 12).

\section{Discussion}

The retrospective nature of our study affected the sample size and the quality of 
the analysis of certain parameters. The non-completeness and loss of some records excluded some newborns from the study; the imprecision of some anthropometric parameters taken by the nursing staff made their analysis difficult. The average age of the mothers was 24.5 years with extremes of 13 and 45 years (Table 1). They were therefore relatively younger than in the series by Diarra AK. in Mali, Charpak $\mathrm{N}$ et al. in Colombia and Kabore et al. in Burkina Faso, who found 26, 27.3 and 29.7 years respectively [3] [4] [5]. These differences could be explained by the different socio-cultural conditions of the peoples where these studies were conducted, but on the other hand by the increasingly early sexuality of adolescents. According to the last demographic health survey in Mali, $18 \%$ of women aged 25 - 49 were already in union before reaching the exact age of 15 , and $53 \%$ were already in union before the exact age of 18 ; the median age at first sexual relation was 16.5 years for women aged 25 - 49 [6].

Table 1. Socio-demographic characteristics of mothers.

\begin{tabular}{|c|c|c|}
\hline Parameters & Number & Percentage (\%) \\
\hline \multicolumn{3}{|l|}{ Age of mothers } \\
\hline$\leq 20$ years & 271 & 28.4 \\
\hline 20 - 39 years old & 664 & 69.5 \\
\hline$>40$ years & 20 & 2.1 \\
\hline \multicolumn{3}{|l|}{ Marital status } \\
\hline Married & 821 & 86.0 \\
\hline Single & 134 & 14.0 \\
\hline \multicolumn{3}{|l|}{ Level of education } \\
\hline Not in school & 443 & 46.1 \\
\hline Primary & 348 & 36.3 \\
\hline Secondary & 122 & 12 \\
\hline Superior & 47 & 4 \\
\hline \multicolumn{3}{|l|}{ Employment } \\
\hline Housewife & 862 & 88.3 \\
\hline Employee & 114 & 11 \\
\hline \multicolumn{3}{|l|}{ Parity } \\
\hline Primiparous & 356 & 37.0 \\
\hline Pauciparous & 338 & 35.2 \\
\hline Multiparous & 264 & 30 \\
\hline \multicolumn{3}{|c|}{ Number of newborns/pregnancy } \\
\hline Unique & 923 & 85.1 \\
\hline Twins & 150 & 13.8 \\
\hline Triplet & 8 & 0.7 \\
\hline Quadruplet & 3 & 0.3 \\
\hline
\end{tabular}


The frequency of low birth weight was higher in mothers aged 20 - 39 years (65.9\%); our results were similar to those of Guillemette et al. in Quebec who found a higher proportion (91.9\%) for the same age group [7]. The majority of mothers (86\%) were married, which is consistent with the results of the Mali demographic and health survey, which found that just over eight out of ten women $(81 \%)$ were in union at the time of the survey [6]. Charpak et al. in Colombia also found that the majority of mothers were in a couple (62.3\%) [8]. On the other hand, studies in Burkina Faso and Nigeria showed that single women were more likely to deliver preterm babies [9] [10]. This indicates that marital status had no influence on the occurrence of prematurity. The majority of mothers in our study were uneducated (46.1\%) and housewives (74.7\%). In Mali, according to EDS-M VI, two thirds of women (66\%) had no education [6]. Other studies carried out in Mali by Diakite N. and Diarra I. had reached the same conclusions with respective rates of $89.1 \%$ and $65.7 \%$ of housewives [11] [12]. Our results are similar to those of Kabore et al. in Burkina Faso (77.7\%) [5]. On the other hand, in Yaoundé, Miaffo et al. in 2008 did not find any significant difference between women with an income-generating activity and those with no employment in relation to the delivery of PPN [13]. The majority of mothers (77.7\%) lived in urban areas (45 minutes from the hospital). In Dakar, P.M. Faye et al found that $26.5 \%$ of mothers lived in urban areas [14]. Access was therefore easy and inexpensive, but this did not have a positive influence on mothers' attendance. This could be due to the low economic level of our households. The low birth weight babies were mostly born to primiparous mothers (36.3\%). This result is close to that of Faye PM. et al in 2013 in Dakar (35.5\%) and that of Diarra A. in Bamako (40.8\%) [14] [15]. The results of the literature concerning the associations between parity and prematurity are discordant, with few good quality studies [16].

Fifty-six percent of the mothers had received at least four antenatal care visits (ANC) during the pregnancy. Our results are not consistent with those of Diarra AK, Balaka and Prazuck et al. who showed that poor compliance with ANC was a contributing factor to preterm or low birth weight delivery [3] [9] [17]. Malaria $(17.5 \%)$ and anaemia (15\%) were the most frequent pathologies during pregnancy. The role of malaria among the etiological factors of prematurity had been demonstrated by several studies [3] [10] [17] [18]. NDiaye et al. found malaria to be the only maternal pathological factor [19]. This could be explained by the fact that malaria is a serious pathology in pregnant women in endemic zones and is responsible for the threat of premature delivery. The multiple pregnancy rate in our series (14.9\%) was comparable to that of Diakite in Mali (16.3\%), Balaka in Togo (17.7\%) and Diagne in Senegal (13.7\%) [11] [17] [20]. Multiple pregnancies can induce overall prematurity, whether spontaneous or induced [16]. The majority of premature babies (56.5\%) followed at the kangaroo unit had a median gestational age of 32 weeks (32 - 34) with a slight representation of the female sex (54\%). The majority of deliveries took place in a health facility $(98.3 \%)$ and by vaginal delivery (86.9\%). The average of birth weight was $1300 \mathrm{~g}$ (Figure 1). This result is lower than that of Ugochukwu et al. in Nigeria, who found that 
$46.6 \%$ of premature babies weighed between 1500 and $1990 \mathrm{~g}$ [21]. Thirteen percent of the newborns were followed up to 24 months (Table 2). According to the results reported by Sidibé in 2012, over a period of 2 years and in the same

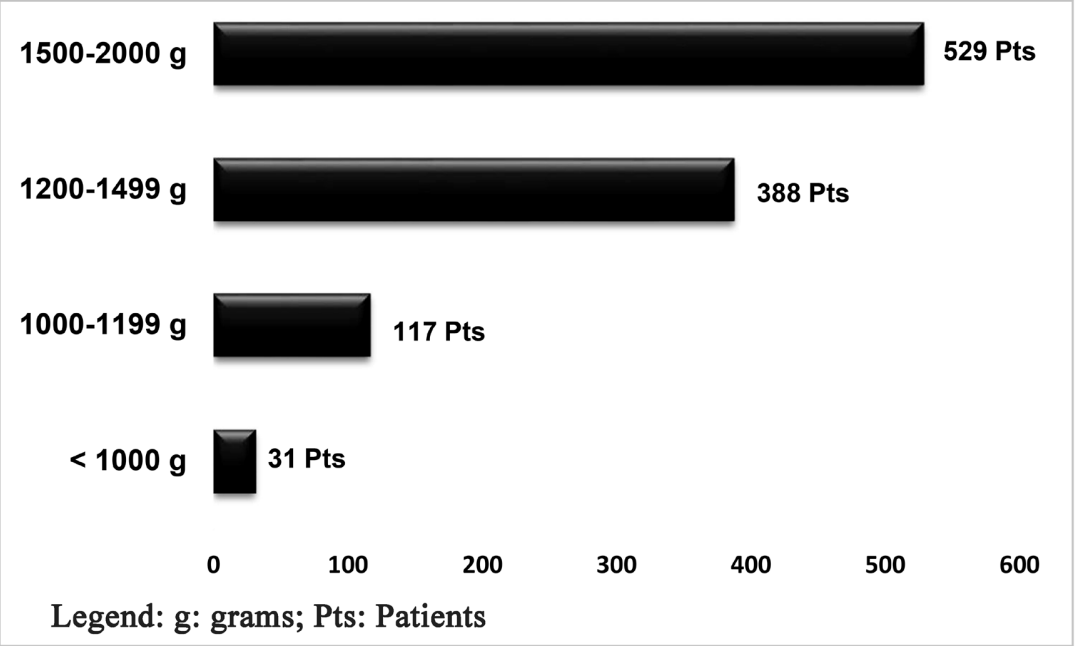

Figure 1. Distribution of newborns by birth weight.

Table 2. Characteristics of newborns.

\begin{tabular}{|c|c|c|}
\hline Parameters & Number & Percentage \\
\hline \multicolumn{3}{|l|}{ Place of birth } \\
\hline Third level hospital & 215 & 20.2 \\
\hline Second level hospital & 509 & 47.7 \\
\hline Community Health Centre & 243 & 22.8 \\
\hline Home & 18 & 1.7 \\
\hline Private clinic & 81 & 1 \\
\hline \multicolumn{3}{|l|}{ Delivery route } \\
\hline Lower track & 912 & 87 \\
\hline Caesarean section & 137 & 13 \\
\hline \multicolumn{3}{|l|}{ Sex } \\
\hline Female & 572 & 54 \\
\hline Male & 488 & 46 \\
\hline \multicolumn{3}{|l|}{ Outcome } \\
\hline Follow-up to 24 months & 150 & 13.8 \\
\hline Stop of tracking & 41 & 4 \\
\hline Lost to follow-up & 608 & 56.1 \\
\hline Transfers to other mother and Child unit & 13 & 1.2 \\
\hline Abandonment of care & 27 & 2.5 \\
\hline Deaths & 69 & 6.4 \\
\hline Ongoing monitoring & 176 & 16.2 \\
\hline
\end{tabular}


unit, this follow-up rate was only $11.1 \%$ [22]. This low follow-up rate could be explained firstly by the mother stopping the practice of "kangaroo-mother" care on discharge from hospital, the death of the baby during follow-up, lack of resources and probably the family's lack of adherence to the practice of the program [23]. The rate of loss to follow-up was very high in our series (56.1\%). This percentage is higher compare to Samuel et al. (20\%) and Laura (13\%) [23] [24] series. The non-adherence of the family to the program, the lack of means for the program to actively search for the lost to follow-up (telephone follow-up, home visit) and the financial difficulties of the parents to pay the numerous visits to the hospital could explain this high rate. We recorded (69) deaths and the letality rate was $6.4 \%$, which is higher than Nathalie's Charpak et al. (3\%) study. Our letality is lower than Tereza's Toma study in Brazil (14.1\%) [25] [26]. Comparing our results with those of Sylla et al. we note a decrease in mortality from 7.9 in 2011 to $6.4 \%$ in 2010 . However, it occurred earlier in hospital $(60 \%$ of cases). Sylla et al. reported more deaths in the interval between discharge and gestational age of 40 weeks [27]. Maternal age over 40 years, non-education and poor socio-economic conditions of the mothers, female gender, weight $<1000 \mathrm{~g}$ and gestational age of the newborns below 32 were associated with the occurrence of death. But on bivariate analysis, none of these factors had an influence on mortality.

\section{Conclusion}

The mother-kangaroo method is an alternative means of improving the survival of premature and low birth weight newborns in Mali. Raising parents' awareness at the time of admission will allow good long-term follow-up of patients.

\section{Conflicts of Interest}

The authors declare no conflicts of interest regarding the publication of this paper.

\section{References}

[1] March of Dimes, Partnership for Maternal, Newborn \& Child Health (PMNCH) and Save the Children, World Health Organization (WHO) (2012) Born Too Soon: The Global Action Report Preterm Birth. Howson, C.P., Kinney, M.V. and Lawn, J.E., Eds., World Health Organization, Geneva.

[2] Ruiz-Pelaez, J.G., Charpak, N. and Cuervo, L.G. (2004) Kangaroo Mother Care, an Example to Follow from Developing Countries. BMJ, 329, 1179-1181.

https://doi.org/10.1136/bmj.329.7475.1179

[3] Diarra, A.K. (2007) L'accouchement prématuré dans le service de gynécologie obstétrique du centre de santé de référence de la commune I du District de Bamako de janvier 2006 à Décembre 2007 à propos de 195 cas. Thèse de Doctorat d'Université, Médecine, University of Sciences, Techniques and Technology Faculty of Medicine and Odontostomatology, Bamako.

[4] Charpak, N., Ruiz-Pelaez, J.G., de Figueroa, C.Z. and Charpak, Y. (1997) Kangaroo Mother versus Traditional Care for Newborns $\leq 2,000$ Grams: A Randomized Controlled Trial. Pediatrics, 100, 682-688. https://doi.org/10.1542/peds.100.4.682 
[5] Kabore, P., Donnen, P. and Dramaix-Wilmet, M. (2007) Obstetrical Risk Factors for Low Birth Weight at Term in Rural Sahel. Santé Publique, 19, 489-497. https://doi.org/10.3917/spub.076.0489

[6] Institut National de la Statistique (INSTAT), Cellule de Planification et de Statistique Secteur Santé-Développement Social et Promotion de la Famille (CPS/SS-DSPF) and International Coaching Federation (ICF) (2019) Mali Demographic and Health Survey 2018. Institut National de la Statistique, Cellule de Planification et de Statistique Secteur Santé-Développement Social et Promotion de la Famille and International Coaching Federation, Bamako and Rockville.

[7] Badlissi, D., Guillemette, A. and Fadin, A. (2001) Prematurity and Low Birth Weight: Effects of Active and Passive Smoking during Pregnancy. Canadian Journal of Public Health, 92, 272-275. https://doi.org/10.1007/BF03404959

[8] Charpak, N., Ruiz-Peláez, J.G., Charpak, Y. and Martinez, R. (1994) Kangaroo Mother Program: An Alternative Way of Carin for Low Birth Weight Infants? One Year Mortality in a Two Cohort Study. Pediatrics, 94, 804-810. https://doi.org/10.1542/peds.94.6.804

[9] Prazuck, T., Tall, F., Roisin, A.J., Konfe, S., Cot, M. and Lafaix, C. (1993) Risk Factors for Preterm Delivery in Burkina Faso. International Journal of Epidemiology, 22, 489-494. https://doi.org/10.1093/ije/22.3.489

[10] Etuk, S.J., Etuk, I.S. and Oyo-Ita, A.E. (2005) Factors Influencing the Incidence of Preterm Birth in Calaba, Nigeria. Nigerian Journal of Physiological Sciences, 20, 63-68.

[11] Diakité, N. (2008) Low Birth Weight Etiology, Immediate Fetal Prognosis in the Reference Health Centre of the Commune V. Doctoral Thesis, University of Sciences, Techniques and Technology Faculty of Medicine and Odontostomatology, Bamako.

[12] Diarra, I. (2010) Low Birth Weight, Etiological Factors and Immediate Fetal Prognosis at the Banconi Community Health Centre in the Commune I of the District of Bamako. Doctoral Thesis, University of Sciences, Techniques and Technology Faculty of Medicine and Odontostomatology, Bamako.

[13] Chiabi, A., Miaffo, L., Mah, E., et al. (2011) Risk Factors and Hospital Prognosis of Low Birth Weight Neonates (Birth Weight Less than 2500 Grams) at the Gynaecological-Obstetric and Paediatric Hospital of Yaoundé, Cameroon. Journal of Paediatrics and Childcare, 24, 125-132.

[14] Faye, P.M., Thiongane, A., Diagne-Guèye, N.R., Ba, A., Gueye, M., Diouf, S., et al. (2016) Kangaroo Care for Low Birth Weight Neonates at the Albert-Royer National Children's Hospital in Dakar. Archives de Pédiatrie, 23, 268-274.

https://doi.org/10.1016/j.arcped.2015.12.010

[15] Diarra, A. (2011) Live Newborns of Low Birth Weight, Etiological Factors and Immediate Fetal Prognosis at the Reference Health Centre of the Commune I of the District of Bamako. Doctoral Thesis, University of Sciences, Techniques and Technology Faculty of Medicine and Odontostomatology, Bamako.

[16] Torchin, H. and Ancel, P.-Y. (2016). Epidemiology and Risk Factors of Prematurity. Journal de Gynécologie Obstétrique et Biologie de la Reproduction, 45, 1213-1230. https://doi.org/10.1016/j.jgyn.2016.09.013

[17] Balaka, B., Baeta, S., Agbèrè, A.D., Boko, K., Kessie, K. and Assimadi, K. (2002) Risk Factors Associated with Prematurity at the University Hospital of Lomé, Togo. Bulletin de la Société de Pathologie Exotique, 95, 280-283.

[18] Chiesa Moutandou-Mboumba, S. and Mounanga, M. (1999) Prematurity in Gabon, a Medical and/or Social Problem. Médecine d Afrique noire, 46, 435-441. 
[19] Ndiaye, O., Fall, A.L., Sylla, A., et al. (2006) Etiological Factors of Prematurity at the Regional Hospital of Ziguinchor, Senegal. Bulletin de la Société de Pathologie EXotique, 99, 113-114.

[20] Diagne, N.R. (2000) Perinatal Characteristics and Fate of Premature Babies in 277 Cases. Thèse de Doctorat d'Université, Université Cheick Anta Diop Faculté de Médecine et d'odontostomatologie, Dakar.

[21] Ugochukwu, E.F., Ezechukwu, C.C., Agbata, C.C. and Ezumba, I. (2002) Preterm Admissions in a Special Care Baby Unit: The Nnewi Experience. Nigerian Journal of Paediatrics, 29, 75-79. https://doi.org/10.4314/njp.v29i3.12027

[22] Sidibé, M. (2012) Suivi de la croissance et du développement neurologique des petits poids de naissance à 24 mois. Dissertation of DES of Pediatrics, University of Sciences, Techniques and Technology Faculty of Medicine and Odontostomatology, Bamako.

[23] Nguah, S.B., Wobil, P.N.L., Obeng, R., Yakubu, A., Kerber, K.J., Lawn, J.E., et al. (2011) Perception and Practice of Kangaroo Mother Care after Discharge from Hospital in Kumasi, Ghana: A Longitudinal Study. BMC Pregnancy and Childbirth, 11, Article No. 99. https://doi.org/10.1186/1471-2393-11-99

[24] Laura, Y. and Ricardo, M. (2000) Kangaroo Mother Program in the Civil Hospital of Guadalajara. 3rd International Workshop on Kangaroo Mother Care, Yogyakarta, 22-25 November 2000.

https://fundacioncanguro.co/wp-content/uploads/2017/10/3rd-international-works hop-List-of-Abstracts-of-those-who-could-not-travel.pdf

[25] Charpak, N., Ruiz-Peláez, J.G., Zita Figueroa, C. and Charpak, Y. (2001) A Randomized, Controlled trial of Kangaroo Mother Care: Results of Follow-up at 1 Year of Corrected Age. Pediatrics, 108, 1072-1079. https://doi.org/10.1542/peds.108.5.1072

[26] Tereza, T. (2019) Kangaroo Mother Care: The Experience of a Public Hospital in Metropolitan Area. https://fundacioncanguro.co/wp-content/uploads/2019/02/abstract26.htm

[27] Sylla, M., Kassogue, D., Traore, I., Diall, H., Charpak, N., Dicko-Traore, F., et al. (2011) Towards Better Care for Preterm Infants in Bamako, Mali. Current Women's Health Reviews, 7, 302-309. https://doi.org/10.2174/157340411796355199 